\title{
EXPERIMENTAL STUDIES ON PHYSIOLOGICAL AND BEHAVIOURAL RESPONSE MECHANISMS OF THE PLANKTONIC COPEPOD EUTERPINA ACUTIFRONS (DANA) TO VARIOUS SALINITIES
}

\author{
G. SOARES MOREIRA and C. YAMASHITA \\ Departamento de Fisiologia Geral, Instituto de Bio- \\ ciências, U.S.P.; Instituto de Biologia Marinha, U.S.P
}

\begin{abstract}
ESTUDOS EXPERIMENTAIS SOBRE OS MECANISMOS DE REAÇÕES FISIOLÓGICAS E COMPORTAMENTAIS DO COPÉPODE PLANCTONNICO EUTERPINA ACUTIFRONS (DANA) A VÃRIAS SALINIDADES
\end{abstract}

\section{RESUMO}

Experimentos sobre regulação volumétrica e testes para verificação de preferência a determinadas salinidades foram realizados com Euterpina acutifrons (Dana). Esta espécie é muito abundante nas amostras de plâncton coletadas no Canal de São Sebastião, cerca de $23^{\circ} 49,6^{\prime} \mathrm{S}$ e $45^{\circ} 25,3^{\prime} \mathrm{W}$. Experimentos sobre regulação volumétrica mostraram que $E$. acutifrons tem capacidade de regular o volume de seu corpo pelo menos dentro dos limites de salinidade entre 25 e $35 \%$. Estes limites estão além daqueles comumente encontrados no biótopo onde esses copépodes foram coletados. Testes sobre preferência a determinadas salinidades mostraram que $E$. acutifrons nāo tem resposta comportamental a variaçōes de salinidade entre as alternativas. Concluiu-se que para um animal de vida planctônica, regulação e adaptação devem ter uma importância ecológica maior do que reações de preferência ou de escape.

\section{ABSTRACT}

\begin{abstract}
Volume regulation and salinity preference tests have been made with Euterpina acutifrons (Dana). This species is very abundant in plankton samples collected in the S. Sebastião Channel, about $23^{\circ} 49,6^{\prime} \mathrm{S}$ and $45^{\circ} 25,3^{\prime} \mathrm{W}$. Volume-regulation experiments have shown that, $E$. acutifrons is capable of regulating its volume inside the range of 25 to $35 \%$. This range is wider than that found in the biotope where the population came from. Preference experiments
\end{abstract}

Número especial em homenagem ao Prof. Dr. Paulo Sawaya, no ano jubilar de seu magistério. 
showed that $E$. acutifrons has no behavioural response to variations in salinity concentrations between the alternatives. It is concluded that, for a planktonic animal, regulation and adaptation must have a higher ecological importance than escape responses.

\section{ACKNOWLEDGEMENT}

This manuscript is dedicated to Prof. Dr. Paulo Sawaya who has greatly stimulated the conducting of experimental work on plankton physiology at the Marine Biology Institute in São Sebastiano.

We thank Dr. Tagea C. Björnberg for reading the manuscript critically.

\section{INTRODUCTION}

Euterpina acutifrons is a planktonic species of Harpacticoidea with a wide distribution in temperate and warm water (Lang, 1948). It is one of the dominant forms along the eastern coast of North and South America. In the São Sebastião Channel, in front of the Marine Biology Institute $\left(23^{\circ} 49,6^{\prime} \mathrm{S}\right.$ and $\left.45^{\circ} 25,3^{\prime} \mathrm{W}\right)$, it occurs throughout the year. In spite of the facilities of rearing this species under laboratory conditions (Bernard, 1964; Neunes and Pongolini, 1965; Haq, 1965; Moreira and Vernberg, 1968; Nassogne, 1969, 1970; Fanta, 1970) scarcely anything is known about its physiologiacal requirements. In this species the males are dimorphic. In addition to the fact that one is distinctly smaller than the other, there are also morphological differences in antennules, antennae and second pair of legs (Haq, 1965). Thermal metabolic acclimation patterns have been determined for these two types of males (Moreira and Vernberg, 1968) and for the females (Vernberg, 1971).

It is known from field studies that $E$. acutifrons occurs in salinities ranging from 8\%o (Tundisi, 1972) to 38\% (El Maghraby, 1965). In the mangrove estuarine region of Cananeia this species does not penetrate till the "marigot" region, with very low salinities, but is very abundant in the regions with salinity above $13 \%$ (Tundisi, 1972). In the laboratory, the salinity resistance of both males and females was measured by Yamashita (1972) in animals caught in São Sebastião Channel and only for females in a short-time experiment by Tundisi and Tundisi (1968) in animals caught in the Cananeia estuarine region. They have found that the lethal salinity $\left(L D_{50}\right)$ for the females was about $8,8 \%$, after six hours of exposure, at approximately $25^{\circ} \mathrm{C}$. Euterpina acutifrons is one of the most resistant species 
of copepods in relation to the lowering of salinity both in Cananeia and São Sebastião regions.

Since the salinity-tolerance limits of this species is so great, this brings up the question of which would be the physiological and behavioural responses of this species to variations of salinity. The present investigation attempts to find out some different response mechanisms of $E$. acutifrons which could be of remarkable importance in the distribution of these animals.

\section{MATERIAL AND METHODS}

\section{A. The animals studied}

Euterpina acutifrons was obtained from horizontal plankton tows in the São Sebastião Channel, in front of the Marine Biology Institute. The water temperature was $24.5^{\circ} \mathrm{C}$ and the salinity was $35 \%$. The tows were made with a N. 20 mesh nylon net. The animals were picked up from the samples soon after capture, placed in culture dishes ( $5.0 \mathrm{~cm}$ bottom diameter, $8.5 \mathrm{~cm}$ top diameter and 5.7 high) covered with a $10 \mathrm{~cm}$ Petri dish top, filled with unfiltered sea water. Each dish received about 50 animals. All experiments on salinity preference were done at the Marine Biology Institute, in São Sebastião. Some animals were brought to the Bioscience Institute, Department of Physiology, São Paulo, kept in a constant temperature box $\left(25^{\circ} \mathrm{C}\right)$ and maintained at a constant salinity $(35 \%$ and $39 \%$ ) at least for 1 week before the experiments on volume regulation. Platymona $s p$ was used as food for the copepods.

\section{B. Salinity and temperature measurements}

All salinity determinations were carried out by titration according to the method of Harvey (1965). Dilution was obtained by adding distilled water to the sea water. The temperature was measured by simple mercury thermomethers (graduated in $1 / 10^{\circ} \mathrm{C}$ ).

\section{Volume regulation}

Direct volumetric measurements have been done for marine eggs, Protozoa and some multicellular organisms (e.g. Prosser, 1965). A simpler technique for harpacticoid copepods is the measurement of 
the total length-variation. As pointed out by Wulff (1972) these length variations reflect even very small change in body volume, due to the specific external morphology of the harpacticoid body. Any change in the body-volume will modify the distances between the body segments, but their diameters will be almost unaffected.

For the volume regulation experiments with $E$. acutifrons, the animals were placed in a special "microaquarium" similar to that described by Gustafson and Kinnander (1956), and figured in Wulff (1972). The only difference is that we did not use a continuous flow of water through the microaquarium. We preferred to change all the water in regular intervals (15 minutes), using a micropipette to add water on one side and sucking it carefully at the other side of the cover with the help of strips of filter paper.

More than 10 experiments were made, but as the variations between them are very small, only two will be figured and discussed in this paper.

The measurements were made projecting the animal profile with the help of a camera lucida (magnification $\mathrm{x} 120$ ) and a stage micrometer slide.

All the experiments were run in a constant temperature room $\left(25^{\circ} \mathrm{C}\right)$.

\section{Salinity preference}

The salinity preference of Euterpina acutifrons was tested in a chamber especially constructed for use with small, motile, aquatic animals. The apparatus and working procedures have been described by Ganning and Wulff (1966).

Several preliminary tests were done to choose the adequate alternative concentrations. A very large difference between the alternatives causes the inactivation of the animals in the lower salinity. Thus, it is not convenient for this kind of experiments, because the animals must be able to move around freely within the whole chamber.

After the preliminary tests, we started the experiments using four separate chambers consecutively, with 10 adult females each. Five animals were placed in each half of the chamber at the beginning of the experiment. Then, a total of 40 animals were studied. In order to test the apparatus, two control experiments were run with the 
same salinity in both halves of the chamber. The two others were made with different salinity in each half of the chamber.

Each experiment lasted two hours, and the number of animals in each half of the chamber was registered each 10 minutes. All these experiments were done at a temperature of $25^{\circ} \mathrm{C}$.

\section{RESULTS AND DISCUSSION}

\section{A. Volume regulation}

Fig. 1 and Fig. 2 show the results of two volume-length regulation experiments with females $E$. acutifrons. When the animal is transferred to a lower salinity, it rapidly swells due to osmotic water-inflow; it reaches a maximum size in approximately 10 minutes. After that the animal begins to regain its original body volume, presenting sucessive variations in size during two hours, when measured each five minutes. The variations were greater at the beginning, and then progressively diminished. After two hours in the lower salinity the length of the animal is still slighty greater than at the beginning of the experiment, before the change of salinity. A longer exposure of the animal in the microaquarium could damage the animal. In order to know if the animal really regains its original size with a longer period, we have placed an animal, after measured, in a small Petri dish with lower salinity, during 24 hours. After that, new measurements are done and we could verify that the length, was exactly the same than at the beginning of the experiment. So, we can conclude that $E$. acutifrons has a complete volume regulation, but in a period longer than two hours.

When Euterpina acutifrons after having been during two hours in less saline water was transferred again to the original salinity to which it was acclimated, it shrinks in five minutes. After that, it regains approximately its original size in one hour. This shrinkage suggests that during the regulation period in lower salinity water the animal looses some ions, besides the water.

The difference between the first experiment (Fig. 1) and the second one (Fig. 2) is the variation of salinity. In the first one, the difference was only $4,5 \%$ and in the second one, the difference was $10 \%$. The swelling caused a variation in length greater in the se- 


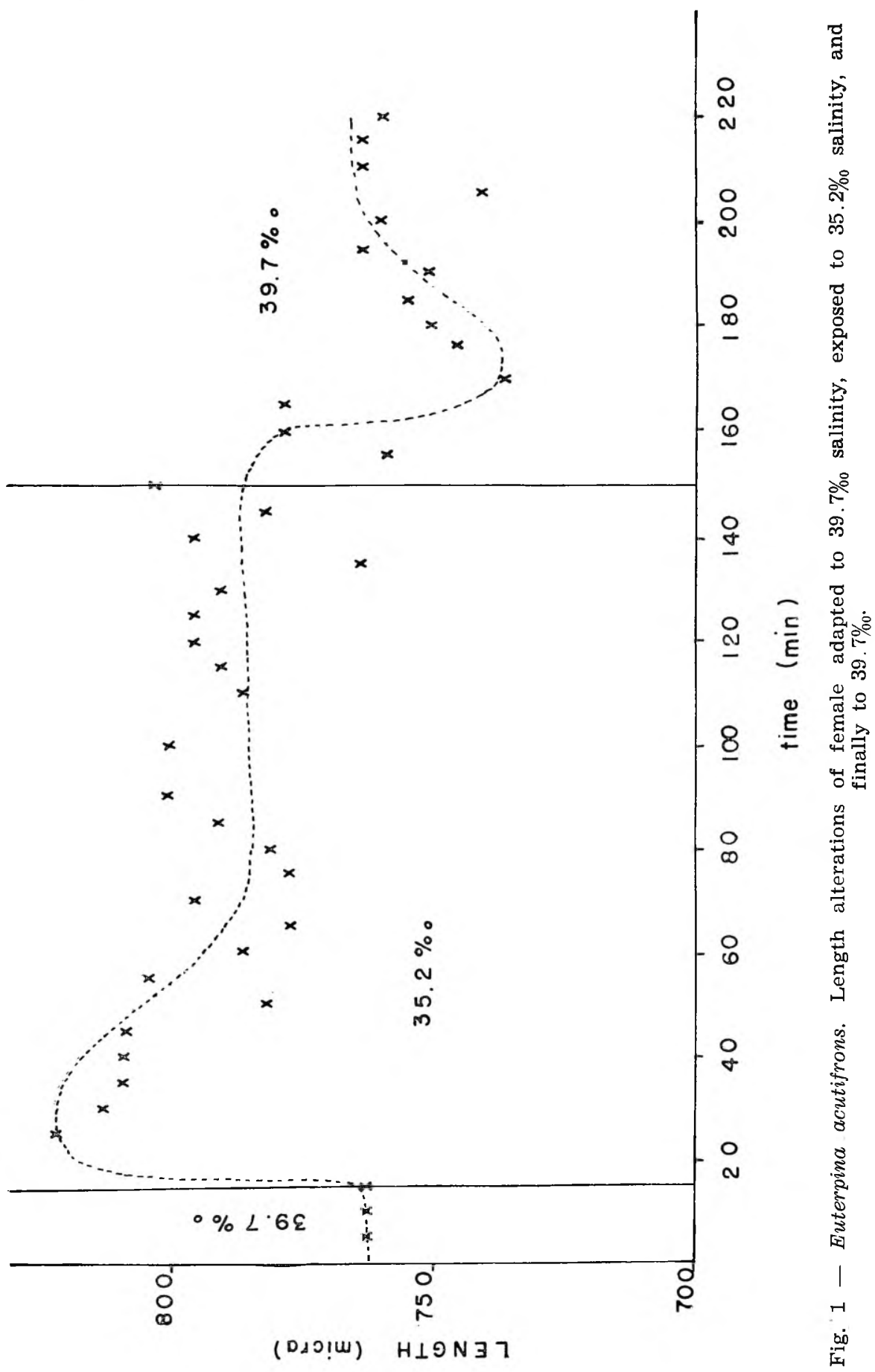




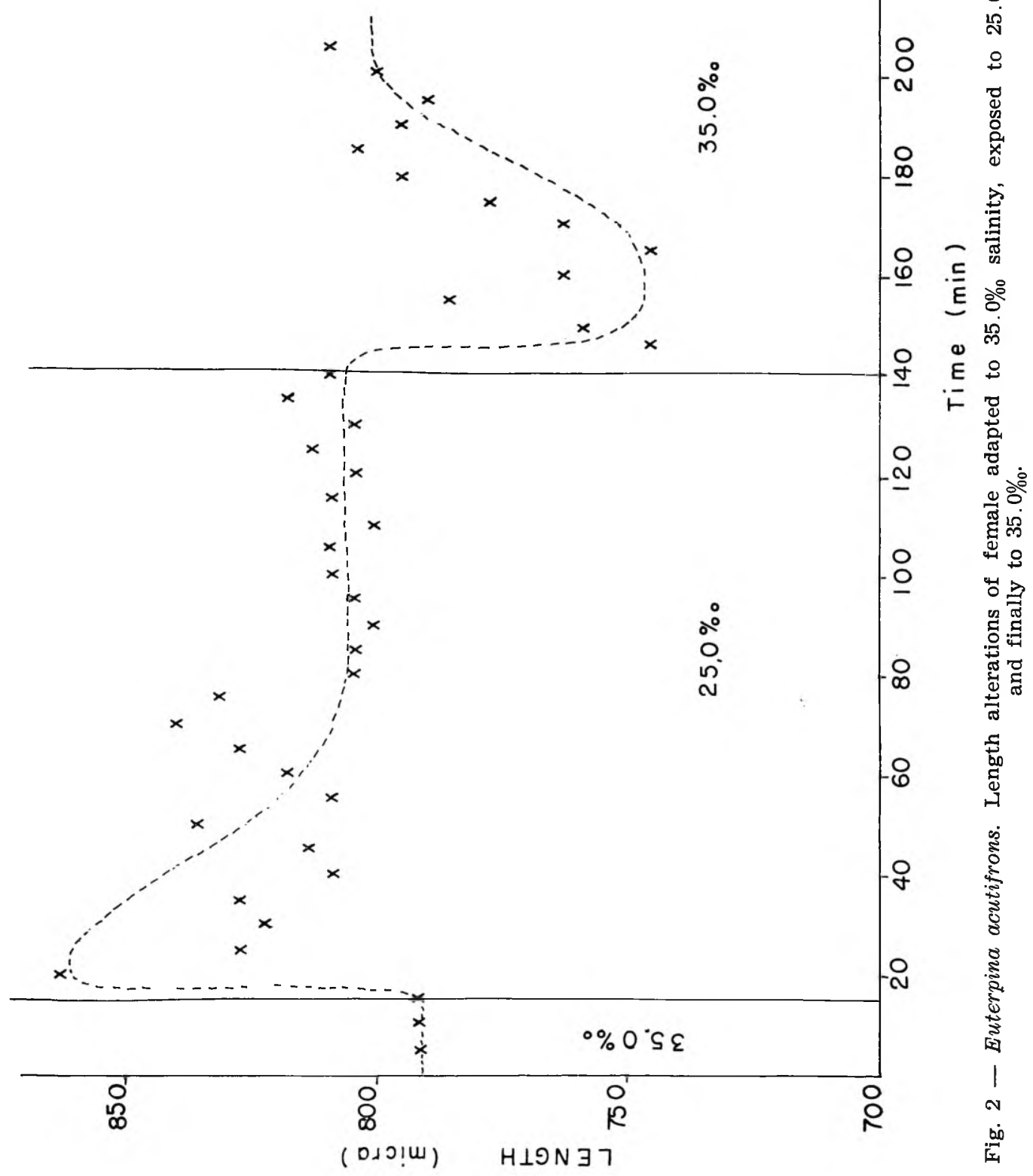


cond experiment (72.7 micra) than in the first one $(59.1 \mathrm{micra})$. Also the shrinkage was greater in the second experiment $(63.6$ micra) than in the first one $(47.5$ micra $)$. This fact was expected since the osmotic water inflow must have been greater in the second experiment than in the first one.

Wulff (1972) ran the same type of experiment with Nitocra spinipes and this animal regained its original size after 105 minutes in lower salinity and after 30 minutes when transferred to the original salinity, i.e. a shorter time than $E$. acutifrons in the above experiments. This fact suggests strongly that Nitocra spinipes is a better regulator than $E$. acutifrons. The capability for volume regulation is an important factor in the mechanism of euryhalinity in marine invertebrates (Schlieper, 1958). Florkin and Schoffeniels (1969) state that the extent or the duration of the swelling (or shrinkage) is inversely related to the euryhaline abilities of a species. As a matter of fact, Nitocra spinipes is more euryhaline than $E$. acutifrons, reproducing, hatching and moulting in salinities from 0.5 to $30.0 \%$ (Wulff, 1972), while E. acutifrons caught in the São Sebastião Channel does not reproduce in salinity lower than 15\% (Yamashita, 1972).

\section{B. Salinity preference}

Numerous experiments were run to discover the preferred salinity range of Euterpina acutifrons. However, no clear picture could be obtained due to the lack of the behavioural response of this species to salinity gradients. Very large differences in salinity between the alternatives were tried, but could not be used, because they cause inactivity. It is known from laboratory experiments (Yamashita, 1972 ) that $E$. acutifrons caught in the São Sebastião Channel, where the salinity is around $35 \%$, has its optimum for survival in salinities between 30 and $35 \%\left(t=25^{\circ} \mathrm{C}\right)$. Thus two experiments were made using $25 \%$ salinity in one half of the chamber and $35 \% 0$ in the another one. This difference $(10 \% 0)$ was chosen, first because it was harmless to the animals and, second, because differences greater than that are very uncommom in nature. Two control experiments besides were run with the same salinity $(35 \% 0)$ on both sides of the chamber.

Fig. 3 and Fig. 4 show the results of the experiments. No clear preference $\left(\mathrm{X}^{2}<3.9, \mathrm{p}>0.05\right.$ in all observations) for one alternative was shown. In conclusion it can be stated that the animals did 


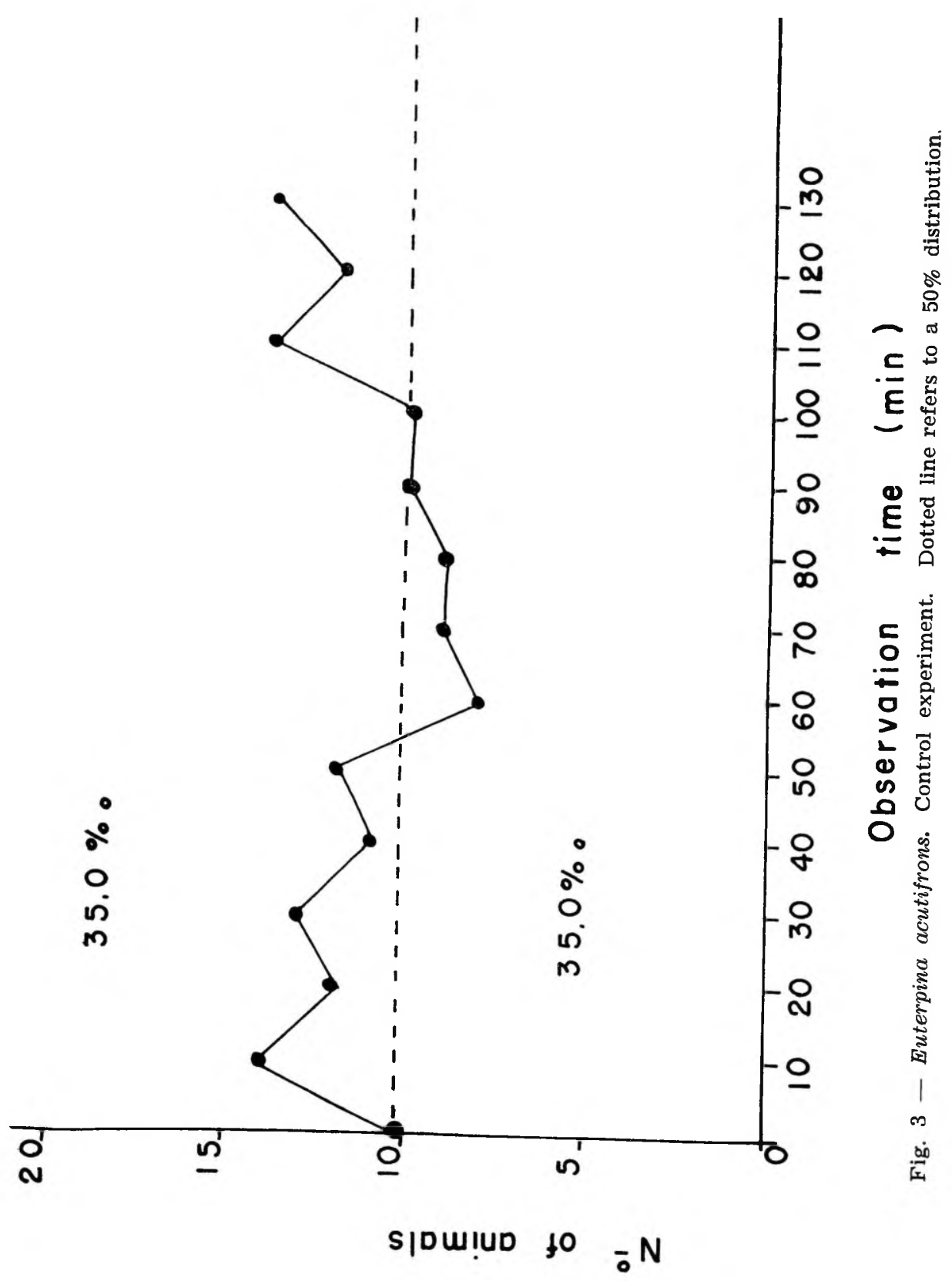




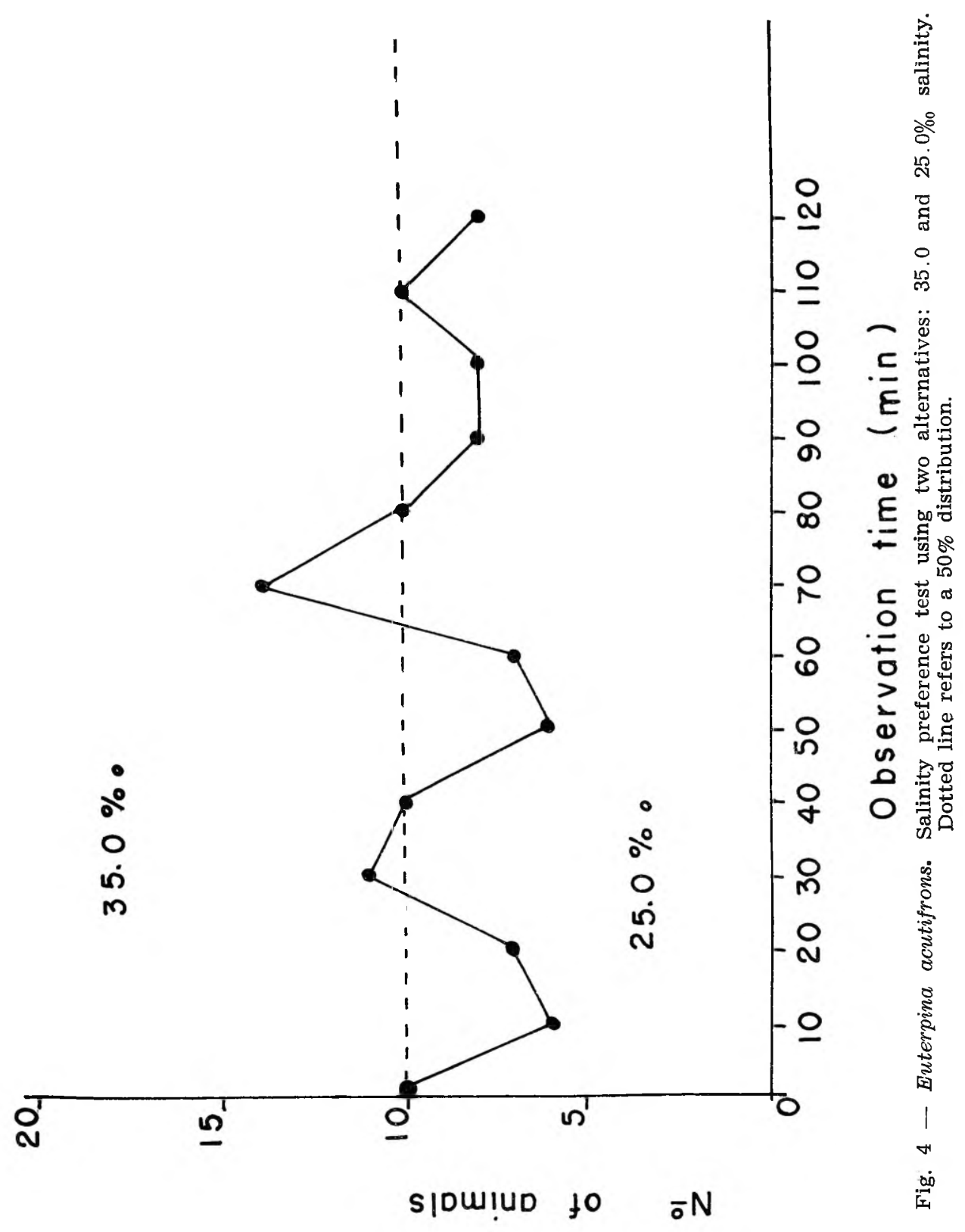


not show a preference for neither of the salinities tested, nor an escape response from one of the salinities. The fact that there was not an escape response is confirmed by the preliminary tests, when very large differences were offered in the alternatives, and after some minutes almost all of the animals were in the lower salinity, where they became inactive. The difference of $10 \%$ of salinity between the alternatives is well within the E. acutifrons regulatory capacity, even upon sudden exposure (as shown by then volume-regulation experiments).

Some experiments of the same type were run with Harpacticoid copepods living in rockpools (Ganning and Wulff, 1966; Wulff, 1972) and also with the interstitial fauna of a sandy beach (Jansson, 1968), but no reference was found for planktonic copepods. The copepods living in a sandy beach have shown a greater preference for some salinities than those living in the rockpools. Wulff (1972) pointed out that the escape reactions must be very advantageous for the copepods living in the sandy beach, which according to Jansson $(1966,1967)$ is a highly unstable microenvironment, characterized by strong gradients within short distances. For the rockpools copepods, such escape responses would be of no value, since salinity changes affect the whole biotope in the same magnitude. For the planktonic animals also the escape responses would be of no value, because they are carried out by the marine currents and it would be impossible, due to its weak power of locomotion, to swim against these currents. Thus, regulation and adaptation must have a higher ecological importance in the distribution of these animals.

\section{R E F E R E N C E S}

BERNARD, M. (1964) - Le cycle vital en laboratoire d'un Copépode pélagique de Mediterraneé Euterpina acutifrons Clauss. Pelagos Bull. Inst. Oceanogr. Alger, $1(2): 35-48$.

EL-MAGHRABY, A. M. (1965) - The seasonal variation in length of some marine planktonic copepods from the eastern Mediterranean at Alexandria. Crustaceana, 8(1):37-47.

FANTA, E. (1970) - Estudo da Anatomia das fases naupliares do copepode Harpacticoide Euterpina acutifrons. M.Sc. Thesis (unpublished), $45 \mathrm{p}$.

FLORKIN, M. and SCHOFFENIELS, E. (1969) - Isosmotic Intracellular Regulation. In Molecular Approaches to Ecology, edited by Florkin M. and Schoffeniels, E., Academic Press, New York and London, pp. 89-111.

GANNING, B. and F. WULFF (1966) - A Chamber for offering alternative conditions to small motile aquatic animals. Ophelia, 3:151-160. 
GUSTAFSON, T. and H. KINNANDER (1956) - Microaquaria for time lapse cinematographic studies of morphogenesis in swimming larvae and observations on sea urchin gastrulation. Expl. Cell Res., 11:36-51.

HAQ, S. M. (1965) - Development of the copepod Euterpina acutifrons with special reference to dimorphis is the male. Proc. zool. Soc. London, 144(2): 175-201.

HARVEY, H. W. (1955) - The Chemistry and Fertility of Seawaters. Cambridge University Press. $224 \mathrm{pp}$.

JANSSON, B. O. (1967) - Diurnal and annual variations of temperature and salinity of interstitial water in sandy beaches. Ophelia, 4:173-201.

JANSSON, B. O. (1968) - Quantitative and experimental studies of the interstitial fauna in four Swedish sandy beaches. Ophelia, 5:1-71.

L.ANG, K. (1948) - Monographie der Harpacticoiden. Stockholm., 2 vols., 1682 pp.

MOREIRA, G. S. and W. B. VERNBERG (1968) - Comparative thermal metabolic patterns in Euterpina acutifrons dimorphic males. Marine Biol., 1(4): 282-284.

NASSOGNE, A. (1969) - La coltura dei Copepodi in laboratorio. Publ. Sta. Zool. Napoli, 37 suppl.:203-218.

NASSOGNE, A. (1970) - Influence of food organisms on the development and culture of pelagic copepods. Helgoländer wiss. Meeresunters, 20:333-345.

NEUNES, H. W. and G. F. PONGOLINI (1965) - Breeding a pelagic Copepod. Euterpina acutifrons (Dana), in the laboratory. Nature, 208(5010):571-573.

PROSSER, C. L. (1965) - Water: osmotic balance. In Comparative animal physiology, edited by C. L. Prosser \& F. A. Brown, W. B. Saunders Company, Philadelphia, $2^{\text {nd }}$ ed. pp. 6-56.

SCHLIEPER, C. (1958) - Physiologie des Brackwassers. In: Die Biologie des Brackwassers. Die Binnengewässer, edited by A. Remane und C. Schlieper, E. Schweizerbat'sche Verlagsbuchhandlung, Stuttgart, 2:219-330.

TUNDISI, J. and T. M. TUNDISI (1968) - Plankton studies in a mangrove environment. V. Salinity tolerances of some planktonic crustaceans. Bolm Inst. Oceanogr. S. Paulo, 17(1):57-65.

TUNDISI, T. M. (1972) - Aspectos ecológicos do zooplâncton da região lagunar de Cananéia com especial referência aos Copepoda (Crustacea). Ph.D. Thesis (unpublished), $191 \mathrm{p}$.

VERNBERG, W. B. (1971) - Metabolic-Environmental Interaction in Marine Plankton. Arch. Oceanogr. Limnol., Venezia (In press).

WULFF, F. (1972) - Experimental studies on physiological and behavioural response mechanisms of Nitocra spinipes (Crustacea: Harpacticoidea) from brackish-water rockpools. Marine Biol., 13(4):325-329.

YAMASHITA, C. (1972) - Fisioecologia e fisiotologia de Euterpina acutifrons (Dana) (Crustacea, Copepoda). Influência da salinidade. M.Sc. Thesis (unpublished), $49 \mathrm{p}$. 